\title{
Targeted Representation? An Analysis of the Appointment of Liberal Candidates in the 1993 and 1997 Federal Elections
}

\section{Miriam Koene*}

\begin{abstract}
This paper analyzes the appointment of candidates made by the leader of the Liberal Party prior to the 1993 and 1997 federal elections. It argues that the appointments made by the leader were only in part a response to the expectations that political parties should become more descriptively representative of the Canadian population. Further, the paper raises a number of concems regarding the use of the leader's appointment power in order to ensure a more descriptively representative party and legislature. It is argued that while other potential reforms were ignored, a rather minimalist and centralizing strategy was utilized. Expectations regarding descriptive representation and conventions concerning candidate selection in Canadian political parties are briefly considered in order to place the 1993 and 1997 nominations in context.
\end{abstract}

In the periods preceding the 1993 and 1997 federal election campaigns, the leader of the Liberal Party of Canada intervened in the candidate nomination process in a number of constituencies by appointing candidates. These actions were defended, particularly in 1997, on the grounds that the Liberal Party wanted to ensure that, at a minimum, 25 per cent of its candidates would be women. In both 1993 and 1997 Jean Chrétien's actions were widely criticized for being needlessly authoritarian and an inappropriate interference with the convention that candidate selection was a matter for local constituency associations and party members rather than for the party leadership.

This paper analyzes these interventions in the nomination processes of 1993 and 1997. It seeks to address whether these interventions can be explained, as claimed by Chrétien, as a measure to ensure that the candidates

Past Imperfect, Vol. 7, 1998, pp.55-86 
would be more representative of the Canadian population, particularly in terms of the number of women candidates. It also explores the use of the leader's appointment power as a means to ensure a more descriptively representative Parliament. The paper concludes that Chrétien's actions were only in part a response to recent expectations that political parties should be more representative of the Canadian population and argues that other factors, such as the nomination of particular "star" candidates, were also at play. Furthermore, the paper raises some concerns regarding the use of the appointment power to ensure a greater number of women candidates and suggests that while other potential, and perhaps more appropriate reforms were ignored, a rather minimalist and centralizing strategy which could ultimately undermine political participation and intraparty democracy was adopted by the leader of the Liberal Party. In order to place the 1993 and 1997 nominations in context, the paper first briefly considers expectations for descriptive representation and also sketches the conventions regarding candidate nomination which have developed in Canada.

\section{DESCRIPTIVE REPRESENTATION}

In recent decades political parties have been confronted with the expectation that they should more accurately reflect the diversity of the Canadian population. They have been called upon by many of the groups involved to be more inclusive and to provide for the better representation of women, visible minorities, and Aboriginal peoples.' The final report of the Royal Commission on Electoral Reform and Party Financing (RCERPF) noted that many of the groups and individuals who appeared before the Commission or submitted briefs "wanted to reflect on how they were represented in Parliament as members of an identifiable group or community of interest-as members of ethno- 
cultural communities, as Aboriginal people, as women."2 Such expectations are not limited to political parties but permeate the political process. For example, in recent rounds of constitutional negotiations various Aboriginal organizations and women's groups have demanded that "one of their own" be directly involved in political decision making. ${ }^{3}$ Demands for recognition have also been evident in proposals for institutional reform. During discussions on Senate reform in the process leading to the Charlottetown Accord, for instance, the National Action Committee on the Status of Women (NAC) wanted to broaden the meaning of equality in order to emphasize gender and minority representation as well as regional/ provincial representation. ${ }^{4}$ It was argued that if disadvantaged or marginalized regions and/or provinces need Senate representation, the principle could be extended to include disadvantaged or marginalized groups. ${ }^{5}$

This emphasis on the direct representation of various groups points to a descriptive form of representation. In descriptive representation, representatives are in some respects typical of a larger class of persons to which they belong. ${ }^{6}$ Emphasis is placed on the identity of the representative and demands are made for "political presence;" that is demands "for the political inclusion of groups that have come to see themselves as marginalized or silenced or excluded." Representational institutions are thought to be more responsive to various social groups if a sufficient number of members from these groups are part of the decision making process. As Jane Arscott and Linda Trimble point out, "representation 'as if women matter,' is more likely to occur when it is undertaken both by and for women."8 In recent years, the focus has been on the under-representation of women, visible minorities, and Aboriginals."

Descriptive representation, however, has not been without its share of critics. Hannah Pitkin, for example, 
raised the concern that descriptive representation "does not allow for an activity of representing." That is, "think of the legislature as a pictorial representation or a representative sample of the nation, and you will almost certainly concentrate on its composition rather than on it activities."10 Another common concern centers on the question of what characteristics and identities will be selected. In other words, "once the characteristics of the people are acknowledged as relevant, there is said to be a potentially endless list of groups that will all claim the same kind of attention, and no legitimate basis for distinguishing between some of these groups and others." feared, if descriptive or mirror representation is taken to an extreme the very possibility of representation itself becomes questionable. ${ }^{12}$

Criticisms of descriptive representation, however, tend to ignore that Canada has a tradition of descriptive representation and concern over particular ascriptive characteristics of representatives is hardly a new feature of Canadian political life. Traditional concerns have centered predominately on regional and/or provincial identity, on the one hand, and linguistic/cultural identity on the other. In the first decades following Confederation, representational concerns included a religious component and a balance between rural and urban ministers was also a goal. Thus Sir John A. Macdonald was very careful that his first cabinet have the proper balance of regional representation, anglophones and francophones, Catholics and Protestants, Scottish, Irish, and English members. ${ }^{13}$ These ministers were seen not only as representatives from specific areas and groups, but also as representatives for these areas and groups. ${ }^{14}$ While the groups and identities which are considered politically relevant and warrant direct representation may have changed over time, the principle of recognizing particular groups has been long established in Canadian politics. 
Canadian political parties have played a significant role in this process. They have functioned as the "gatekeepers" in the political system, helping to determine who is included and represented and who is not. Parties help shape and direct political issues and identify the groups which have a stake in the issues. ${ }^{15}$ Given that parties help determine who/ what becomes represented, it is not surprising that parties have been called upon to reform themselves in order to become more inclusive. Parties need to confront fundamental questions of equality which arise given the persistent under-representation of 50 per cent of the population. They need to reform their practices to provide for better representation of historically marginalized groups of Canadians.

TRADITIONS OF CANDIDATE NOMINATION IN CANADA

As R. K. Carty writes, there is a "long and valued tradition of local autonomy" regarding candidate selection in Canada; local party activists have traditionally guarded the right to determine who will be their candidate for Parliament. The nomination process is one of the few times when constituency associations "spring to life."16 This localism sets Canada apart from candidate selection in Britain, for example, where there is greater centralization and standardization. ${ }^{17}$ However, this tradition of local autonomy is not the only tradition, as a more centralized approach is also evident at times.

During Canada's first party system, from about 1867 to 1917 , party politics was decentralized and focused on the constituency level. ${ }^{18}$ In this period it became firmly established that candidate selection fell to local partisans; they had the right to determine who their candidate would be and the manner in which the candidate would be chosen. ${ }^{19}$ Parties were "little more than coteries of political notables" where local party associations and supporters 
were linked through their MP, or defeated candidate, to the leadership at the centre. ${ }^{20}$ Although there were no standard rules or procedures that were followed, and practice varied from constituency to constituency, local party activists would typically come together in a recognized meeting to select and nominate a candidate. ${ }^{21}$

During the second party system, from about 1921 to 1957, the focus of politics shifted from the constituency to the regional level. ${ }^{22}$ Candidate nomination was influenced by strong regional leaders, particularly in the governing Liberal Party. Further, during this period the central party took a greater role in the candidate nomination process and parties began the practice of running a candidate in every constituency. This meant that at times local party members in "hopeless" ridings needed help in finding candidates. We see, then, the development of a more centralized approach to candidate nomination. The Liberal Party in Newfoundland and the Social Credit Party in Alberta are perhaps the most stark examples of this approach. Liberal candidates in Newfoundland for federal and provincial elections were essentially selected by Premier Joseph Smallwood. As Robert Williams notes, he "made no secret of his ability to nominate candidates as part of his personal prerogative." 23 The leader of the Alberta Social Credit Party, William Aberhart, also selected all the Social Credit candidates. Local involvement was restricted to allowing constituency conventions to nominate three or four candidates, from whom Aberhart would select the candidate. ${ }^{24}$ Yet, as R. K. Carty and Lynda Erickson argue,these centralizing aspects did not completely eliminate the localism of candidate nomination, but "they did add to the complexity of nomination processes, often by operating through the old forms."2s Furthermore, the Progressive Party counteracted these centralizing tendencies and worked to make the nomination process responsive to the local level. ${ }^{26}$ 
During the third party system, which began in about 1963, a few diverse developments in candidate nomination occurred. On the one hand, this period has witnessed the growth of open and competitive nomination meetings. As Carty and Erickson note, this has tended to reinforce the tradition of localism and grassroots participation in the nomination process. Yet, there are a number of trends which have resulted in even greater centralization of the nomination process. First, there has been a greater institutionalization of party organization with the development of centralized national campaign planning. Second, the perceived costs associated with nomination contests have become a concern. And third, as noted above, parties have been increasingly called upon to be more inclusive, and especially, to nominate more women. ${ }^{27}$

A key development in this period was a change to the Canada Election Act in 1970 which resulted in the registration of parties. In 1966 a parliamentary committee on election expenses had recommended that parties be recognized as legal entities so that campaign financing could be regulated ${ }^{28}$ The registration of parties meant that party affiliation appeared on the ballots as well. As John Courtney notes, if party affiliation appeared on the ballot, the possibility of having more than one candidate for a particular party would not be possible. It follows then that someone in the parties would have to certify who would be the party candidate and this responsibility fell to party leaders. Effectively, then, party leaders were given a formal veto over candidates. Soon after, in 1974, Conservative leader Robert Stanfield used this veto and refused to endorse a candidate due to the candidate's views on bilingualism. Other examples of a leader using the veto include Prime Minister Brian Mulroney's veto of Sinclair Stevens and the veto of a Reform candidate in British Columbia by Preston Manning. In order to avoid the nomination of candidates embroiled in corruption scandals, 
Prime Minister Kim Campbell discussed the possibility of preventing several Conservative candidates from running in 1993 while Liberal leader Jean Chrétien made no apologies for refusing to sign the nomination papers of a number of candidates. ${ }^{29}$

The Liberal Party took the centralization of nominations one step further in 1992 when it provided the leader of the party with the power to appoint candidates, rather than simply veto local choices. To understand the reasons behind this change, it is necessary to consider Liberal nomination contests in 1984 and 1988.

\section{LIBERAL CANDIDATE SELECTION IN THE 1980S AND THE ADOPTION OF THE APPONNTMENT POWER}

The Liberal Party experienced a number of divisive nomination battles prior to the 1984 and 1988 elections. As Carty and Erickson point out, "Groups concerned with a single issue (e.g. abortion), or which represent some identifiable social group (e.g. an ethic community), have begun to move in and take over local party associations, often driving out party regulars in the process. ${ }^{30}$ One example of this was the success of anti-abortionist Tom Wappel in the 1988 Liberal nominations. Wappel defeated Patrick Johnston with the help of the anti-abortion group Campaign Life, which mobilized support for Wappel.3" Johnston had been recruited by John Turner and was a former director of the National Anti-Poverty Organization and co-chair of the Liberal Party's platform committee.

It should be noted, however, that in 1988 for instance, about two-thirds of all party nominations were won by acclamation. Most party nominations thus "can best be characterized as relatively uncompetitive, modest events." Nevertheless, although few in number, the divisive nomination battles and the recruitment of "instant" party members for the purposes of voting at a nomination 
meeting pose a number of problems. As Erickson and Carty suggest while "ethnic mobilization ... has some positive potential for parties seeking to expand their base at election time, single-issue mobilization poses considerably more difficulties." 33 Particularly the single issue mobilization efforts centered on an issue such as abortion may be seen as a threat to parties which "are remarkably open and hence vulnerable to external capture" by individuals with little commitment to the party. ${ }^{34}$ Further, given the attention by the media, the divisive and vicious nomination battles can be an embarrassment to a party.

As a result of these nomination battles and in part as a response to concerns over the cost of nominations, the Liberal Party created, in 1990, a special Reform Commission whose mandate included making recommendations on "the establishment of a permanent electoral commission." 35 The Reform Commission's interim report noted that "in some ridings we have had major problems with the selection of candidates for election ... [and] the 1984 and 1988 elections were marked by events which reflected badly on the reputation of the Party as an open, accessible, democratic and fair institution." 36 The Reform Commission suggested that a national Nominations Commission be created which would administer and regulate all aspects of the candidate selection process. It would be mandated to draw up rules and would act as a "court of last resort" for nomination disputes." While the 1992 Liberal Convention rejected the proposed Nominations Commission, delegates did accept the establishment of a "Permanent Appeal Committee," As outlined in Article 15 of the Liberal Party Constitution, the Permanent Appeal Committee would:

15(2) ... be responsible for establishing rules of procedure related to appeals arising from candidate nominations. 
$15(3) \ldots$ be responsible for the adjudicating appeals in the provinces and territories arising from candidate nominations. ${ }^{39}$

More significantly, the Convention also approved a proposal which would allow the national party to establish rules, subject to change by the provincial associations, for the selection of candidates. The Party Constitution was changed to the following:

14(6) Following consultations with the National Executive and the Executive Committee of each provincial and territorial association, the National Campaign Committee shall adopt and publish rules regarding the procedures to be followed in the nomination of candidates to represent the Liberal Party of Canada in any general election or by-election. These rules may be varied from province to province or territory by the Campaign Committee of the respective province or territory in consultation with the executive of provincial or territorial association. ${ }^{40}$

Stemming from these changes, all Liberal Party local nomination meetings must now be authorized by the relevant Provincial or Territorial Association's Campaign Committee, which in return must receive permission from the National Campaign Committee before approving any nomination dates. ${ }^{41}$ The most publicized and controversial change after the 1992 Convention, however, was the power given to the leader to appoint candidates. The National Rules for the Selection of Candidates, adopted and published by the National Campaign Committee in April 1992, detail the power of the leader to appoint as follows:

2.3 After consultation as set out in subrule 2.4 , the Leader of the LPC may decide that a meeting shall not 
be held in an electoral district and shall designate a person who will be the candidate for an electoral district in any election.

2.4 Before designating a candidate as described in subrule 2.3, the Leader of the LPC shall consult with the national campaign co-chairs of the national campaign committee and the chair of the relevant provincial or territorial campaign committee who shall consult with the executive of the constituency association. ${ }^{42}$

Rather ironically, it may be noted, that while open and competitive nominations may have encouraged grassroots participation, it also has resulted in greater central control of nominations in order to avoid divisive and expensive nomination battles. Yet, while the leaders of other parties may have utilized the veto power as well as behind-thescenes maneuvers, only the Liberal Party moved to provide its leader with the power to appoint candidates.

By allowing the leader to appoint candidates, the Liberal Party centralized its nomination process to a greater degree than had previously been the case. Further, the motivation behind the leader's appointment power was not exclusively, or even primarily, in order to ensure the nomination of more women, but rather as a means to prevent single-issue candidates from securing a Liberal nomination. The paper now turns to an examination of how the appointment power was actually used by the leader of the Party in 1993 and 1997.

APPLICATION OF THE APPONTMENT POWER IN 1993 AND 1997

In 1993 Chrétien, using his prerogative as leader of the Liberal Party, by-passed the regular constituency nomination practices and appointed fourteen candidates. ${ }^{43}$ These appointments were often justified as necessary in order to secure a greater number of women candidates. 
Speaking to the Party's national election campaign committee, Chrétien said he was prepared to appoint candidates in order to ensure that 25 per cent of the Liberal candidates would be women: "We have not achieved our goal of having 25 percent women ... so we have to do something about it ... I will have to appoint some. It will be positive affirmative action." ${ }^{\text {"4t }}$ Sheila Copps, the deputy leader, also indicated that appointments would be used to meet the 25 per cent target. 45

The appointments in 1993 were as outlined in Table 1.

While Chrétien's justifications in 1993 that appointments were necessary to ensure 25 per cent of Liberal candidates would be women, clearly that was not the only rationale as a number of his appointments were men. During the 1993 campaign the Liberal Party emphasized its team and often pointed to its "star" candidates. It is therefore not surprising that Chrétien used his appointment power in 1993 to guarantee that "stars" such as Arthur Eggleton and Marcel Massé would be candidates. ${ }^{47}$ In addition to the appointment of "stars," Chrétien also used his appointment power to prevent Liberals for Life from securing Liberal nominations. ${ }^{48}$ Liberals for Life was a faction within the Liberal Party which had ties to the pro-life group Campaign Life Coalition and which mobilized around single-issue antiabortion candidates in a number of ridings. ${ }^{49}$ In EtobicokeLakeshore Chrétien appointed Jean Augustine to prevent Dan McCash, who was a member of Liberals for Life, from contesting the Liberal nomination. ${ }^{\text {so }}$ The appointments of Maria Minna and Georgette Sheridan also blocked anti-abortion candidates. ${ }^{\text {s1 }}$ Finally, the appointment power was used to protect incumbents. Derek Lee and David Berger, who were sitting Members of Parliament expecting to face strong nomination battles, were both appointed..$^{52}$ 


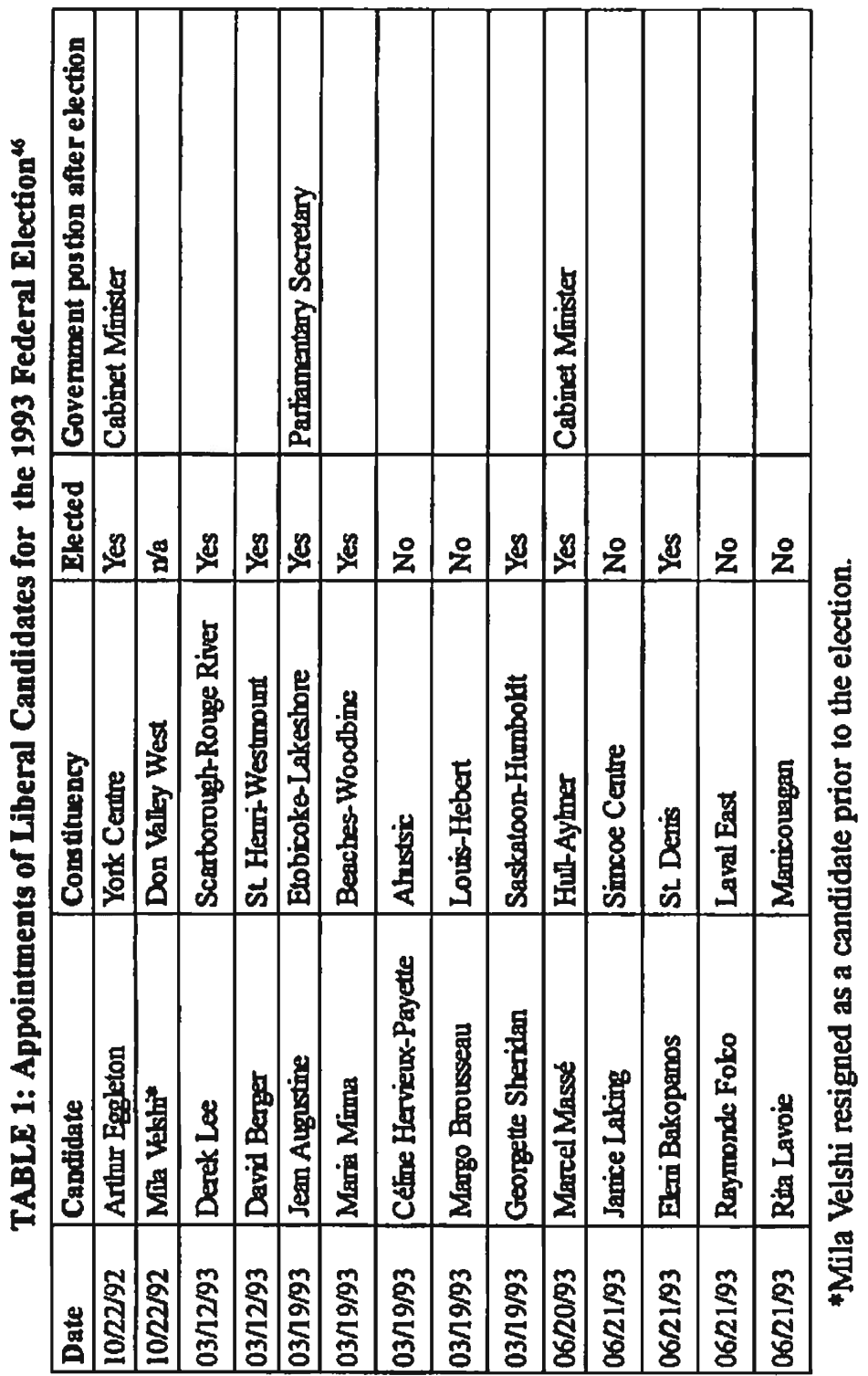


The appointments in 1993 were controversial within the Liberal Party. In Toronto three Liberals, former cabinet minister John Munro, Peter Li Preti and Albert Kergi, held a press conference to announce a court challenge to the nomination process. They accused Chrétien of undermining the democratic process by appointing candidates and allowing appointed officials to intervene in the local nomination process. ${ }^{53} \mathrm{Li}$ Preti was seeking the York Centre nomination before Eggleton was appointed. Neither did the appointment of the two incumbents, Lee and Berger, go unnoticed. The appointment of Berger in Westmount was controversial as Donald Johnston, the Party's president, had hoped to seek the nomination, and had the support of many local party activists. ${ }^{54}$ The media reported that local members believed Chrétien "placed caucus solidarity before democracy" when he appointed Berger."s In Scarborough-Rouge River, where Lee was appointed, the supporters of former riding association president Gobinder Singh Randhawa had sold "thousands" of memberships. ${ }^{56}$ In Hull-Aylmer the riding association executive was upset by Chrétien's appointment of Massé. ${ }^{77}$ The executive refused to support Massé and worked instead for their preferred candidate, Tony Cannavino, who ran as an Independent. The riding president termed the appointment of Massé as "a dictatorial and autocratic approach." 58 Similarly, in Simcoe-Centre, where Laking was appointed, most of the local association resigned in protest and the former riding president Ed O'Reilly decided to run as an Independent. ${ }^{59}$ As noted above, the nominations of Augustine, Minna, and Sheridan were controversial as well and were particularly criticized by anti-abortionists.

It may also be noted that the controversy over the nomination process was not restricted to those ridings where the Prime Minister appointed a candidate. In BromeMissisquoi, for example, a candidate was not formally 
appointed, yet local Liberals protested the manner in which the nomination was managed by Quebec Liberal organizer Senator Rizzuto. After some behind-the-scenes maneuvers, Joan Kouri sought the nomination unchallenged. Rizzuto asked potential candidate Gibbs, who had worked on securing the nomination for over a year, to bow out of the race because the riding needed a high-profile woman. ${ }^{60}$

Despite the appointments in 1993, the Liberal Party did not meet its own target of 25 per cent, and secured only 22 per cent women candidates. ${ }^{61}$ of the fourteen appointments in 1993, eight were elected, five were defeated, and one, Velshi, resigned prior to the election. The elected candidates included Eggleton, Lee, Berger, Augustine, Minna, Sheridan, Massé, and Bakopanos. Of these Eggleton and Massé (both men) were appointed to the cabinet while Augustine was appointed as a parliamentary secretary.

In 1997 Chrétien used his appointment power more sparingly than he had in 1993:

TABLE 2: Appointments of Liberal Candidates for the 1997 Federal Election

\begin{tabular}{|l|l|l|}
\hline Candidate & Constituency & Elected \\
\hline Elimor Caphan & Thombill & Yes \\
\hline Sophia Leung & Vancouver-Kingsway & Yes \\
\hline Judi Longfield & Whitby-Ajax & Yes \\
\hline Judy A. Sgro & Yotk South-Weston & No \\
\hline Karen Redman & Kitchener Centre & Yes \\
\hline Sarkis Assadourian & Brampton-Centre & Yes \\
\hline
\end{tabular}

As in 1993, Chrétien often mentioned his commitment to the goal of having at least 25 per cent women candidates. 
He also emphasized that the Liberal Party was trying to put women in ridings where they had a good chance of winning. ${ }^{62}$ This same theme was later echoed by National Campaign Co-Chair Senator Hervieux-Payette who noted that: "We have nominated women in winnable ridings. Our efforts prove that the Liberal Party is very serious about increasing the number of women in Parliament." ${ }^{\text {"63 }}$ Penny Collenette, Chrétien's head of appointments, also emphasized that the appointment power was necessary in order to have more women running for Parliament: "We do need more women at the table and Mr. Chrétien is able to see that as a goal and an objective, and I think it's a worthy one." ${ }^{164}$ After Chrétien appointed four women on March 11 he stated, "I am thrilled that these outstanding women have agreed to run as Liberal candidates. The Liberal Party is committed to ensure that our caucus reflects the diversity of Canadian society."6s

Chrétien's rationale for the appointment of women received widespread criticism from the media, opposition parties, the caucus and from local party members. Chrétien had argued in a speech that "It's difficult for women to come into politics. ... The financial concerns for them; the family responsibilities are, for some, a very significant barrier." "The problem is, none of the four women he appointed last week fall into this category." ${ }^{167}$ Another editorial stated that "these are not disadvantaged people. They are some of the most articulate and influential citizens in the country. To suggest prominent women in the Liberal Party are incapable of contesting and winning a nomination democratically is itself an act of discrimination." It also suggested that Chrétien acted in a paternalistic and arrogant manner.68

The appointments were also criticized by members of other political parties and by some members of the Liberal caucus. The Reform Party's Status of Women Critic, 
Sharon Hayes, claimed she was "amazed at the demeaning mentality Jean Chrétien's Liberals have toward women." She also stated "this kind of patronizing treatment of women has to end. No woman worth her salt wants a seat in Parliament that she has not won in a fair and democratic way." ${ }^{269}$ Reform MP Deborah Grey was also very critical: "Any woman who takes part in that kind of stuff, I take pity for." Conservative MP Elsie Wayne claimed to "find it an insult to me and all women." The Liberal caucus was divided over the appointments. Minister Sergio Marchi suggested that Caplan, for example, "could have obviously held her own. She has no problem fundraising." Some Liberal women MPs spoke out against the appointments as well, while others defended the practice."

The appointments, as in 1993, were particularly controversial among local party members in the ridings. In the case of Vancouver-Kingsway, where Liberal Party leadership feared a nasty and divisive nomination battle, three male candidates were by-passed in favour of Sophia Leung, a social worker. ${ }^{2}$ Two of the men considered running as independents as a consequence of the appointment. ${ }^{3}$ One of them, Raymond Leung (no relation to the candidate), subsequently joined the Reform Party and attempted to obtain the Reform nomination. ${ }^{74}$ The appointment of Elinor Caplan, a Liberal MLA and former Ontario Health Minister who lived near the riding of Thornhill but not in it, was not without controversy either. Earlier in the year, the general secretary of the riding wrote to National Co-Chair David Smith asking him not to make an appointment: "We feel that an appointment, at this 11th hour, will only serve to hamper the momentum." Vincenza Spagnolo, chair of the Liberal election committee in the riding, wrote that "non-elected backroom boys" undermined the democratic process. ${ }^{75}$ Three candidates were campaigning for the nomination prior to Caplan's appointment. ${ }^{76}$ 
The other appointments appeared to be somewhat less controversial. Judi Longfield had served as a Municipal Councilor in Whitby, Ontario. Judy Sgro, a Metro Councilor for North York-Humber, faced former Liberal John Nunziata, for whom she had previously worked, in York South-Weston. ${ }^{7}$ On April 23 Chrétien appointed a fifth woman at the request of a local executive. After sitting Member of Parliament John English announced that he would not seek re-election, the executive of the Kitchener Centre Liberals adopted a motion on April 20 unanimously requesting the appointment of Karen Redman. ${ }^{78}$

In addition to the appointment of women candidates, the Liberal Party also publicized the fact that its Judy LaMarsh Fund had raised more than $\$ 150,000$ in order to help women Liberal candidates. Chrétien stated, "The Liberal Party is very serious about increasing the number of women in the House of Commons. We are determined to ensure that female candidates get the financial help they need."79 The President of the Fund, Marian Maloney, noted, "In every election we are increasing the amount of financial support we provide female candidates. Liberals in all parts of the country, women and men, are very committed to see Parliament become truly representative of our population." "The Judy LaMarsh Fund was able to offer candidates approximately $\$ 2,000$, although female incumbents were asked if they would be willing to opt out of the Fund. In 1984 it had raised enough to offer women candidates $\$ 550$ and in 1988 the fund provided $\$ 850$ per candidate. ${ }^{81}$

While the Liberal Party was particularly careful in 1997 to emphasize the link between the number of women candidates and Chrétien's appointments, he did appoint one man as well. Liberal MP Sarkis Assadourian, who lost his Toronto riding of Don Valley North due to the redrawing of electoral boundaries, was appointed in the newly-drawn riding of Brampton Centre. ${ }^{82}$ In addition, it 
was reported that Chrétien had considered a proposal from his national campaign committee to designate sitting MPS in order that they could avoid potential nomination challenges. ${ }^{83}$

While six appointments were formally made, a number of other ridings were targeted as possibilities for an appointment. In Nepean-Carleton the nomination process, which had been frozen, was reopened in the face of opposition from local Liberals. Controversy developed after it was rumored that Chrétien was considering appointing one of his female staffers despite the fact that three women (in addition to one man) came forward to contest the nomination. ${ }^{84}$ Another such riding was NotreDame-de-Grace, which had been held by Warren Allmand since 1965. After the Prime Minister appointed Allmand as president of the International Centre for Human Rights and Democratic Development, Labour Minister Alfonso Gagliano, head of the Liberal campaign in Quebec, met with the riding association to discuss the Liberal nomination. Gagliano had said that while he wanted to keep the nomination open, he would prefer a female candidate in the riding, and would not rule out an appointment. The president of the riding association, Stanley Baker, "made it quite clear" that they did not want an appointed candidate: "We want to decide for ourselves. We do not want anyone imposed on us."

The fact that a number of the female Liberal MPs in Atlantic Canada faced nomination challenges also raised the possibility of appointments. In the end, however, no appointments were made in the Atlantic region. This was perhaps because two of the women facing challenges, Jean Payne and Roseanne Skoke, were both controversial during the last Parliament. Payne was being investigated on numerous counts of fraud while Skoke had criticized the government on issues and legislation dealing with the rights of gays and lesbians. Further, the co-chairs in the Atlantic 
provinces resisted appointments. Senator HervieuxPayette, National Campaign Co-Chair, said she spoke with election co-chairs in the Atlantic provinces, noting that: "They all said they don't want any appointments, it's not helping their candidates. There's a resentment out there against appointments. There's a feeling that it undermines the credibility of our candidates. I trust the judgment of the people there." ${ }^{186}$ Hervieux-Payette also said that if the Liberals do not meet their 25 per cent target in Atlantic Canada it would even out in the rest of the country. ${ }^{87}$

In addition to Skoke and Payne, Pierrette RinguetteMaltais was a third Atlantic woman MP whose nomination was challenged. Although she was not appointed by the Prime Minister, local Liberal association members accused the provincial co-chairs of giving Ringuette-Maltais an unfair advantage when it set the nomination meeting time and place without consulting the new riding's executive. ${ }^{88}$ Ringuette-Maltais' riding changed due to the new electoral boundaries and about 40 per cent of her old riding fell under the new riding of Tobique-Mactaquac. The nomination meeting was set for Grand Falls which was part of Maltais' old riding and was a francophone community.

Controversies surrounded the Liberal nomination process in a number of other ridings in 1997 as well. In Edmonton-North, where MP John Loney was retiring, local party members accused the Party leadership of parachuting in Jonathan Murphy, former director of the Edmonton Social Planning Council. The local organizers of Edmonton-North claimed that Jake Vanderschaaf, who collected 400 memberships, was the only candidate. However Claudette Roy, one of the Alberta Liberal campaign co-chairs, said Vanderschaaf was not registered as a nominee for the candidacy and that only Jonathan Murphy was registered as a nominee. Murphy had been seeking the nomination of Edmonton-Strathcona but 
switched to Edmonton-North. ${ }^{89}$ Roy refused to sign the nomination papers of Vanderschaaf and at the February 4 nomination meeting Murphy was acclaimed as the candidate. ${ }^{90}$

In the new riding of Burnaby-Douglas Tom Esakin, who planned to run for the nomination, claimed that party backroom maneuvers resulted in Mobina Jaffer being acclaimed as the candidate. The nomination meeting was set for January 15 and Jaffer was the only candidate. ${ }^{91}$ There was also controversy in the riding of Renfrew-NipissingPembroke, where Liberal MP Len Hopkins announced he would not seek re-election. Hec Clouthier unsuccessfully challenged Hopkins for the nomination in the last election and then proceeded to run as an Independent. Under the Liberal Party of Canada (Ontario) rules, Clouthier would be banned from party membership for five years but the Party endorsed his run for the candidacy, despite criticisms from the local party association. David Smith said it was his prerogative, under his power as National Campaign Co-Chair, to endorse Clouthier. ${ }^{92}$

In 1997 the Prime Minister and his campaign co-chairs used the appointment power more sparingly than in 1993. Furthermore, in 1997 there was a much more consistent effort than in 1993 to emphasize that the reason for appointments was to secure a greater number of women candidates. While there was some behind-the-scene action to secure the nomination of a number of male candidates, only one was actually appointed, Assadourian, who had lost his riding due to redistribution. By contrast, in 1993, four men had been appointed, two of whom where considered "stars" and two of whom were incumbents facing strong nomination challenges.

The target of 25 per cent was met in $1997 ; 28$ per cent of Liberal candidates were women. It should be noted, however, that 26 per cent of Liberal candidates would have been women even without any of the appointments by the 
leader. Of the six appointments, only Sgro was defeated in the election, losing to Independent candidate John Nunziata. None of the five appointed candidates who won in the election were appointed as ministers or as parliamentary secretaries.

\section{THE APPOINTMENT POWER AS A MEANS TOWARD DESCRIPTIVE REPRESENTATION?}

The appointment power, then, was not used only to secure a greater number of women. It was used, particularly in 1993, to guarantee the nomination of "star" candidates (some of whom were men), to protect incumbents, and to avoid potentially divisive and embarrassing nomination battles such as had occurred in 1984 and 1988. Furthermore, in both 1993 and 1997, in addition to the formal appointments, the Prime Minister and his national campaign team worked behind-the-scenes to secure the nomination of their desired candidates, not all of whom were women. While the Prime Minister may have wanted to secure a greater number of Liberal women candidates, that was certainly not the only factor at work. If the Liberal Party was truly dedicated to the goal of increasing the number of women, the question remains as to why the rather minimalist target of 25 per cent was selected when women comprise 50 per cent of the population.

Beyond the doubts concerning the depth of commitment of the leader of the Party to obtaining a more descriptively representative set of candidates, are questions concerning the desirability of the appointment power as a mechanism to secure a greater number of women candidates. We have seen that the leader's appointment of candidates raised considerable concern among the grassroots of the party. On more than one occasion the local party executive was strongly opposed to the candidate appointed by Chrétien. Often other potential nominees, who had already been 
canvassing support and selling party memberships, complained bitterly about the appointment process. At times they ran as Independents. Thus the appointments ran the risk of alienating the grassroots of the party and undermining political participation and intraparty democracy. Given that this was the case with the modest target of 25 per cent, it would undoubtedly be a greater problem if a more equitable target of 50 per cent was set.

Furthermore, this rather authoritarian response may well be out of step with the wishes of the Canadian population. The Royal Commission on Electoral Reform and Party Financing (RCERPF) the Spicer Commission, and poll after poll have revealed an electorate that is distrustful of traditional political leaders and that is dissatisfied with the current means of governance. At a time when Canadians are demanding more open and participatory governance, the leader of the Liberal Party selected a rather centralized strategy instead of exploring other means.

While it is beyond the scope of this paper to evaluate the range of alternatives to the leader's appointment power, the leader of the Liberal Party could have pursued other strategies. For example, the recommendations of the RCERPF is a potential starting point for the Party. The RCERPF recommended: spending limits be set on nomination campaigns; political contributions to nomination contests be made eligible for tax credits; childcare expenses be included as an allowable tax deduction for candidates; financial incentives be provided to parties that increase the percentage of women in the House of Commons; and that parties establish search committees to seek out representative candidates. It should be noted, however, that these recommendations still fall short of a commitment to 50 per cent of women Members of Parliament. ${ }^{93}$ The attempts of the New Democratic Party to secure more women candidates may also be instructive. The NDP struggled with the challenge of how to address gender inequalities in representation and has opted for a mandatory process. ${ }^{24}$ 
According to the Affirmative Action Policy, ridings must establish "a candidate search committee" which reflects the diversity of the riding and must ensure that "there is one or more candidate for nomination from affirmative action groups." Each section also has a candidate search committee which works with the ridings to find candidates for nomination. Additional measures include workshops, information packages as well as some financial support for the candidates."s

\section{CONCLUSION}

We have seen that particularly in 1997, but also in 1993, the leader of the Liberal Party claimed his appointment of candidates was in order to obtain a greater number of Liberal women candidates, and thereby obtain a more representative caucus. It has been argued, however, that both the reason behind the Liberal Party granting its leader the power to appoint candidates and the application of that power was not exclusively, or even primarily, due to the desire to obtain a greater number of women candidates. Furthermore, the depth of the commitment of the leader to obtain a more inclusive and representative party is questionable given the rather minimalist target of 25 per cent women candidates. Finally, even if the leader of a party was truly committed to increasing the number of women candidates, the centralizing strategy of appointing candidates is a problematic one given that Canadians are demanding more open and participatory governance.

It is interesting in and of itself, however, that Chrétien and his campaign committee attempted to justify the appointments in terms of securing a greater number of women candidates. Clearly Chrétien wanted to be perceived as being responsive to women voters, perhaps due to the growing evidence of a gender gap among voters and due to the fact that Liberal Party traditionally depends on 
women's votes. A party which has been criticized for neglecting its child care promises, ignoring high unemployment, and cutting social programs, may have needed something in order to retain women supporters. ${ }^{96}$

\section{NOTES}

*The author would like to thank Dr. D. K. Stewart and the anonymous referees of this journal for their helpful comments.

'Alexandra Dobrowolsky and Jane Jenson, "Reforming the Parties: Prescriptions for Democracy," in How Ottawa Spends: A More Democratic Canada...?, ed. Susan D. Phillips, (Ottawa: Carleton University Press, 1993), 49.

${ }^{2}$ Report of the Royal Commission on Electoral Reform and Party Financing, Final Report, Vol.4., Reforming Electoral Democracy: What Canadians Told Us (Ottawa: Minister of Supply and Services, 1991), 39.

${ }^{3}$ For example, see Alan Cairns, "Constitutional Minoritarianism in Canada," in Reconfigurations: Canadian Citizenship and Constitutional Change, ed. Douglas E. Williams (Toronto: McClelland and Stewart, 1995).

4 Shelagh Day, "Speaking for Ourselves," in The Charlottetown Accond, the Referendum, and the Future of Canada, eds. Kenneth McRoberts and Patrick Monahan (Toronto: University of Toronto Press, 1993).

"Will Kymlicka, "Group Representation in Canadian Politics," in Equity \& Community: The Charter, Interest Advocacy and Representation, ed. F. Leslie Seidle (Montreal: The Institute for Research on Public Policy, 1993), 65.

${ }^{6}$ A.H. Birch, Representation (Toronto: MacMillan, 1964), 16.

'Anne Phillips, The Politics of Presence (New York: Oxford University Press, 1995), 5.

${ }^{8}$ Jane Arscott and Linda Trimble, "Introduction," In the Presence of Women: Representation in Canadian Governments (Toronto: Harcourt Brace and Co., 1997), 4.

- The focus in this paper will be on women and while obviously there are difficulties and dangers in treating women as a group. there are also pragmatic reasons to do so on occasion. See for example, Iris Marion Young, "Gender as Seriality: Thinking about Women as a Social Collective," Signs 19 (Spring 1994): 713-38. ${ }^{10}$ Hannah Pitkin, The Concept of Representation (Berkeley: University of Califomia Press, 1967), 90, 226. 
"Phillips, The Politics of Presence, 46.

12 Will Kymlicka, "Group Representation in Canadian Politics," 69.

"See W.L. Morton, "The Formation of the First Federal Cabinet," Canadian Historical Review 36 (June 1955):113-25; and W.L. Morton, "The Cabinet of 1867," in Cabinet Formation and Bicultural Relations: Seven Case Studies, ed. Frederick W. Gibson (Ottawa: Queen s Printer for Canada, 1970), 6.

"Norman MCL. Rogers, "Federal Influences on the Canadian Cabinet," The Canadian Bar Review 2 (Feb. 1933): 119.

is J. Brodie and J. Jenson, "Piercing the Smokescreen: Stability and Change in Brokerage Politics," Canadian Parties in Transition, Second Edition, eds. A. Brian Tanguay and Alain G. Gagnon (Scarborough: Nelson Canada, 1996), 55.

${ }^{16}$ R.K. Carty, Canadian Political Parties in the Constituencies (Toronto: Dundurn Press, 1991), 103, 105.

"Norris et al., "Party Selectorates in Australia, Britain and Canada: Prolegomena for Research in the 1990s," The Journal of Commonwealth and Comparative Politics 28 (July 1990): 222

${ }^{18}$ R.K. Carty and L. Erickson, "Candidate Nomination in Canada's National Political Parties," in Canadian Political Parties: Leaders, Candidates, and Organization, Vol. 13 of the Royal Commission on Electoral Reform and Party Financing, ed. Herman Bakvis (Toronto: Dundurn Press, 1991), 100.

"Carty and Erickson, "Candidate Nomination," 101.

${ }^{20}$ R.K. Carty, "Three Canadian Party Systems," Canadian Political Party Systems (Peterborough: Broadview Press), 564.

"Carty and Erickson, "Candidate Nomination," 100.

${ }^{n}$ Carty, "Three Canadian Party Systems," 571; and Carty and Erickson, "Candidate Nomination," 102.

${ }^{2}$ Robert J. Williams, "Candidate Selection," Canada At the Polls, 1979 and 1980: A Study of the General Elections, ed. Howard R. Penniman (Washington: American Enterprise for Public Policy Research, 1981), 93.

24 Williams, "Candidate Selection," 92.

${ }^{25}$ Carty and Erickson, "Candidate Nomination," 102.

${ }^{26}$ Williams, "Candidate Selection," 94.

${ }^{27}$ Carty and Erickson, "Candidate Nomination," 98-99, 102-104. Also, R. K. Carty, Canadian Political Parties in the Constituencies: A Local Perspective, Vol. 23 of the Royal Commission on Electoral Reform and Party Financing, (Toronto: Dundurn Press, 1991), 104. ${ }^{28}$ John C. Courtney, "Recognition of Canadian Political Parties in Parliament and in Law," Canadian Journal of Political Science 11 (March 1976): 46. 
${ }^{29}$ David Roberts, "PM hints she may act on M.P.s," Globe and Mail, 29 July 1993; Suan Delacourt and Craig McInnes, "Bad Apples Can't Run, Chretien says," Globe and Mail, 29 July 1993, A4.

${ }^{30} \mathrm{Carty}$ and Erickson, "Candidate Nomination," 98.

${ }^{31}$ Graham Fraser, Ploying for Keeps (Toronto: McClelland and Stewart, 1989), 166.

${ }^{32}$ Carty and Erickson, "Candidate Nomination," 120, 128.

${ }^{33}$ Lynda Erickson and R.K. Carty, "Parties and Candidate Selection in the 1988 Canadian General Election," Canadian Journal of Political Science 24 (June 1991):346.

${ }^{34}$ Ibid., 349.

${ }^{35}$ The Reform Commission of the Liberal Party of Canada, Agenda for Reform: Interim Report, (31 July 1991), 1, as found in Michael S. O'Brien, "A Comparative and Historical Analysis of Candidate Practices in the Liberal Party of Canada," (MA Thesis, Dalhousie University, 1993).

${ }^{36}$ Reform Commission, Agenda for Reform, 3.

${ }^{37}$ Reform Commission, Agenda for Reform, 8-9.

${ }^{38}$ O'Brien, "A Comparative Historical Analysis," 117-118.

${ }^{39}$ Liberal Party of Canada, Constitution, Article 15(2).

${ }^{40}$ Liberal Party of Canada, Constitution, Article 14(6).

"Liberal Party of Canada, National Rules for the Selection of Candidates for the Liberal Party of Canada, subrules 3.1 and 3.2, (April 1992), 4.

"Liberal Party, National Rules, 3-4.

"It should be noted that only fourteen candidates were appointed out of a total of 301 Liberal candidates.

"4 "Chrétien May Pick 6 More Candidates," Globe and Mail, 1 February 1993, A4.

"Andre Picard, "Liberals Want Women to Run in 25\% of seats; Copps says Program to Meet Quota Includes Overriding of Nominations," Globe and Mail, 9 March 1993, A4.

${ }^{16}$ Dates of Appointment from O'Brien, "A Comparative and Historical Analysis," 175.

${ }^{17}$ Nancy Wood, "Talking up the team: Liberals Pin Their Hopes on Star Candidates," Maclean's, 2 August 1993, 14.

${ }^{48}$ Sydney Sharpe, The Gilded Ghetto: Women and Political Power in Canada (Toronto: Harper Collins, 1994), 173; "Chrétien may pick 6 more candidates".

49 "NDP Campaign to Stress Abortion Rights," Globe and Mail, 27 January 1993, A8; Paul Wiecek, "Gun Lobby has Grits in Sights," Winnipeg Free Press, 4 June 1997, Al. 
sosydncy Sharpe, The Gilded Ghetto, 173.

"O'Brien, "A Comparative and Historical Analysis," 125.

st Ibid., 124.

"Delacourt and McInnes, "Bad Apples Can't Run, Chretien says." "Lysiane Gagnon, "Voters Long for Someone to Save Them from Chretien," Globe and Mail, 20 March 1993, D3; Graham Fraser, "Chretien Avoids Nomination Fracas," Globe and Mail, 13 March 1993, A1, A8.

ss "Johnston Won't Seek Westmount Nomination," Montreal Gazette, 13 March 1993, Al, as found in O Brien, "A Comparative and Historical Analysis," 125.

${ }^{96}$ Fraser, "Chretien Avoids Nomination Fracas."

37 "Disillusioned with Tories, Liberal Hopeful Masse says," Globe and Mail, 8 July 1993, A8.

s8 "Liberal leader names 4 women as candidates," Montreal Gazette, 22 June 1993, A1, as found in O Brien, "A Comparative and Historical Analysis," 126.

"As found in O'Brien, "A Comparative and Historical Analysis," 127.

"Susan Delacourt, "Ignored Liberals, Decry Parachuting," Globe and Mail, 22 July 1993, A6.

${ }^{6}$ See Appendix 1.

62 Susan Delacourt, "Liberals May Duck Selection Process," Globe and Mail, 10 March 1997, Al, A6.

"Liberal Party of Canada, "Liberal Party Surpasses Goal For Women Candidates," Press Release, 23 April 1997.

"Delacourt, "Liberals May Duck Selection Process."

${ }^{65}$ Liberal Party of Canada, "Chretien Names Four Prominent Women as Liberal Candidates," Press Release, 11 March 1997.

"Delacourt, "Liberals May Duck Selection Process."

6 "Nominating Women," The Hill Times, 17 March 1997.

68 "Women Don't Need PM's Paternalism," Edmonton Journal, 13 March 1997, A14.

"Sharon Hayes, "Liberal Women Need Parachutes," Press Release, 11 March 1997.

${ }^{70}$ Ken McQueen, "Outcry Greets Appointment of Female Candidates by PM: Move Condemned as Undemocratic by Political Rivals and Some Liberals," The Ottawa Citizen, 12 March 1997.

"Jim Brown, "Liberal M.P.s Divided Over Appointing Candidates," Edmonton Journal, 13 March 1997, A3; Ann Sulivan, "Brutal Nomination Battles Main Obstacle for Grit Women," The Hill Times, 17 March 1997. 
72 "PM May Appoint Female Candidate," Edmonton Journal, 20 February 1997, B7.

"Anne Mcllroy, "PM Picks Four Women to Run," Globe andMail, 12 March 1997, A.4.

7 Anne Mcllroy, "Defectors Challenge Liberal Candidate," Globe and Mail, 8 April 1997.

${ }^{73}$ McQueen, "Outcry Greets Appointment of Female Candidates." ${ }^{76}$ Mcllroy, "PM Picks Four Women to Run," A4.

"Mcllroy, "Defectors Challenge Liberal Candidate."

${ }^{78}$ Liberal Party of Canada, "Liberal Party Surpasses Goal For Women Candidates."

79 Liberal Party of Canada, "Judy LaMarsh Fund Raises Over $\$ 150,000$ For Liberal Women Candidates," Press Release, 6 May 1997.

${ }^{\infty}$ Ibid.

"Ann Sullivan, "Liberal Women's Fund Asks For Refund," The Hill Times, 31 March 1997.

82 Joan Bryden, "Not Only Women Benefit When PM Appoints Candidates," Ottawa Citizen, 18 March 1997; Mike Scandiffio, "Orphaned Liberal M.P. Finds New Home: Grit M.P.s Say Party Hierarchy Will Ensure Assadourian Wins Nomination," The Hill Times, 8 January 1997.

"Canadian Press Newswire, "Chretien May Let M.P.s Skip Nomination Process," 31 July 1996.

24 "Liberals Lift Freeze on Ottawa Area Nomination," Globe and Mail, 27 February 1997, A5.

${ }^{35}$ Mike Scandiffio, "NDG Grits Want One of Their Own," The Hill Times, 3 March 1997.

${ }^{85}$ Ann Sullivan, "Atlantic Women Candidates Challenged by Men: Problem for Federal Liberals Who Want 25 per cent of Female Candidates," The Hill Times, 10 February 1997.

87 Thid.

${ }^{*}$ Mike Scandiffio and Ann Sullivan, "Liberals Put Out Nomination Bush Fires," The Hill Times, 27 January 1997.

Ibid.

90 Norm Ovenden, "Candidate's Selection Upsets Liberal Insiders," Edmonton Journal, 25 January 1997, A3.

${ }^{91}$ Scandiffio and Sullivan, "Liberals Put Out Nomination Bush Fires."

"Ibid.

${ }^{93}$ See Jane Arscott, "A Job Well Begun...Representation, Electoral Reform and Women," in Gender and Politics in Contemporary 
Canada, ed. Francois-Pierre Gingras(Toronto: Oxford University Press, 1995).

"Lynda Erickson, "Making Her Way In: Women, Parties and Candidacies in Canada," in Gender and Party Politics, eds. Joni Lovenduski and Pippa Norris (London: Sage Publications, 1993), 80.

${ }^{95}$ New Democratic Party, Nomination and Affrmative Action Policy, 26 May 1996.

${ }^{96}$ Indeed, Brodie and Gotell argue that parties may use incremental increases in the number of women as a substitute for substantive programmatic commitments to women. See, Janine Brodie and Lise Gotell, "Women and Parties in the 1990s: Less Than Ever an Issue of Numbers," in Party Politics in Canada, Seventh Edition, ed. Hugh G. Thorbum (Scarborough: Prentice-Hall Canada Inc., 1996). 


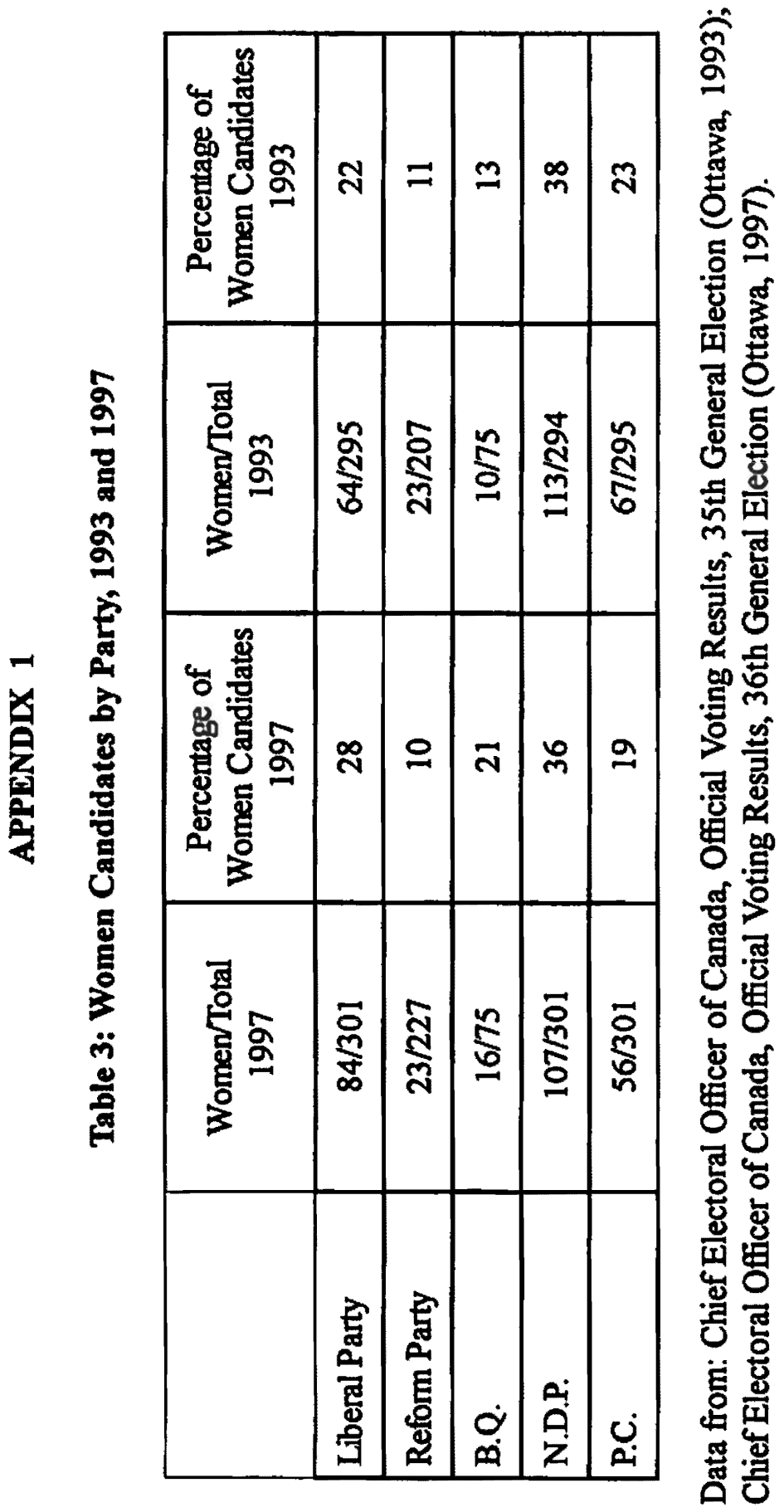




\begin{tabular}{|c|c|c|c|c|c|c|}
\hline 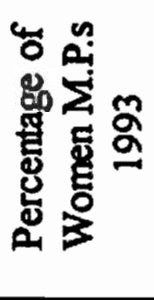 & 유 & $m$ & $\cong$ & $\Rightarrow$ & 요 & $\stackrel{\infty}{\rightarrow}$ \\
\hline 预 & 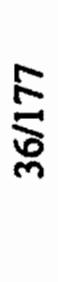 & $\underset{\sim}{N}$ & ஸे & $\stackrel{2}{2}$ & 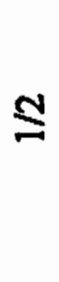 & 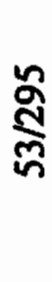 \\
\hline 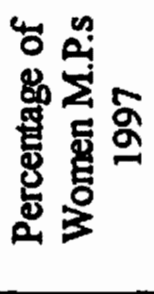 & ম & $N$ & $\approx$ & $\stackrel{\infty}{\infty}$ & 은 & $\vec{v}$ \\
\hline 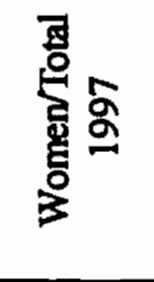 & $\stackrel{n}{\approx}$ & $\frac{8}{8}$ & $\underset{\Xi}{ \pm}$ & $\vec{\infty}$ & 옥 & $\begin{array}{l}\overrightarrow{8} \\
\text { శ్ }\end{array}$ \\
\hline & 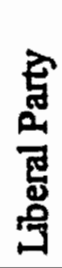 & 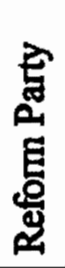 & $\underset{\dot{\theta}}{\dot{\alpha}}$ & 足 & ن & 졍 \\
\hline
\end{tabular}

